Article received on 10 February 2013

Article accepted on 15 February 2013

UDC: $78 ; 050.489$ NEW SOUND

\author{
Nenad Ostojic** \\ University of Novi Sad \\ Academy of Arts \\ Department for Music
}

\title{
VIEWS FROM THE ANALYTICAL ANGLE
}

\begin{abstract}
This paper presents a clear insight into the rich diversity of the range of texts published in the Analyses section, which indicates its place in the complete pool of papers published in the International Magazine for Music New Sound during two decades of its existence. The authorial contributions are grouped according to the genre peculiarities of the subject (a musical work or works) with which they deal analytically, and the consideration of the particular features of the chosen analytical angle is focused on concisely conveying the most important defining characteristics of all the published papers.
\end{abstract}

Keywords: Novi Zvuk, New Sound, analysis, musical genres, formal shaping, structural distinctions

Апстракт: У овом раду остварен је прегледни увид у богату разноликост палете текстова објављених у рубрици Анализе којим се указује на њено место у укупном корпусу радова објављиваних током две деценије постојања Интернационалног часописа за музику Нови Звук. Ауторски прилози су, при томе, груписани по основу жанровске посебности предмета (музичко дело/дела) којим се аналитички баве, а прегледни увид у посебности одабраног аналитичког ракурса фокусиран је на сажето саопштавање најбитнијих одредбених карактеристика сваког објављеног рада.

Кључне речи: Нови Звук, анализа, музички жанрови, формално уобличавање, структуралне посебности

* Author contact information: ostojicn@open.telekom.rs 
Although it was assumed that the items published in other related sections (Studies, Interpretations, New Works...) would also, by the nature of things, have to base their specific views on analytical tools, the Editorial Board of the New Sound magazine, while devising the newly launched publication's concept, had no dilemmas about the need to reserve a separate space where perception from the analytical standpoint would not only be the primary methodological anchorage, but also the ultimate goal. Thus, the Analyses section, ever since the first issue of New Sound published in 1993, has taken up a great deal of the total available space in most of the issues published during the last twenty years. Although views from the analytical angle were not present in all the volumes published so far, 21 authors from Serbia and abroad have published 30 items in this section up to the jubilee fortieth issue, with a total of $338.5(238.5+100)$ pages. Thereby, analytical studies were absent either from those issues which were conceived as thematic (Issues 16, 26, 28, 34, 36) or from those which offered many more texts included in the aforesaid related sections (Issues 23, 25, 31, $35,37)$. The appreciable difference between the number of texts published (30) and the number of their authors (21) suggests that certain individual creative laboratories produced more than one paper: four authors (Sonja Marinković, Marija Masnikosa, Miloje Nikolić and Branka Radović) signed two texts each, one author (Ivana Vuksanović) wrote three texts, and one (Anica Sabo) four published papers (fifteen authors contributed one item each). The genre range of musical works whose particulars have been analytically perceived is wide, running from solo pieces (I), to choral (II) and chamber (III), to concert (IV) and symphonic (V) compositions by, for the most part, contemporary authors, and the gamut has been enriched by digressions (VI) into ballet music, new music technologies, the World Music phenomenon, as well as film and multimedia. Since the items in question are scattered both in time (the last twenty years) and in space (29 issues of the New Sound magazine), what will follow are concise sketches of their content and most prominent features. By choosing such a structure for this clear insight into the rich diversity of the spectrum of papers published in the Analyses section, the author did not intend to perform a sort of, as bureaucrats would say, jubilee inventory of what has been done so far, but to use these concise reviews of the published items as an encouragement for readers to meet with their integral versions, be it for the first time or again.

\section{I}

Among the analytical papers published, only the item 'Klavirska sonata Sofije Gubajduline' ['Piano Sonata by Sofia Gubaidulina'] by Ivana Ćojbašić (Novi Zvuk, 15, 2000) deals with a work for a solo instrument. Moving along 
the timeline of the Sonata, the author first introduces the features of formal solutions of all the movements in a three-movement sonata cycle, and then reports on the perceived particulars of the composer's concept of rhythm, stresses the importance of the procedures that allow Gubaidulina to create a rich instrumental sound, underscores the observed cross-like relationship between vertical and linear parameters as the vehicle of the work's spiritual component, and emphasizes the role of improvisation which the composer uses to open up additional space for performing creativity.

\section{II}

As early as in the second issue of the newly launched publication, Miloje Nikolić published the item 'Razvoj forme rukoveti u srpskoj horskoj muzici između dva svetska rata' ['Development of the Choral Garland Form in Serbian Choral Music between the World Wars'] (Novi Zvuk, 2, 1993), to open up genre space in which he would be joined by two more authors, and thus choral music would be the subject of four analytical texts published in five issues of the magazine. Since this text by Nikolić was a part of his more extensive study, which was still unpublished at the time, the author presented another section of it, belonging to the same subject of scientific interest located in a different time period, through the paper 'Rukoveti i srodne forme u srpskoj horskoj muzici posle Drugog svetskog rata' ['Choral Garlands and Related Forms in Serbian Choral Music after the Second World War'], which was, due to its comprehensiveness, published in two consecutive issues of the magazine (Novi Zvuk, 6, 1995 and Novi Zvuk, 7, 1996). Choosing, therefore, to integrally treat the decades-long development of the pool of domestic choral creation based on the artistic arrangement of folk songs, Nikolić, rightly so, places the garlands by S. S. Mokranjac as the basic landmark for reporting on the features of newly created works. Thus, in the said items, he viewed other authors' choral opuses based on folklore material through the prism of a choral garland as defined in Mokranjac's master workshop: first (in the first paper) P. Konjović, S. Binički, K. Manojlović, J. Slavenski, M. Tajčević, M. Živković, S. Nastasijević and V. Vučković; and then (in the second paper) Lj. Marić, P. Milošević, N. Hercigonja, V. Peričić, R. Petrović, R. Anđelković, D. Trbojević, D. Radić, V. Kostić, V. Simić, D. Obradović, M. Živković, Lj. Frajt, D. Golemović, A. Vujić, M. Aleksinački and M. Kuzmanović. Apart from the analyses of the choral works by these composers, the author also offered a possible systematization of the obtained range of various compositional solutions.

Choral garlands were a subject of yet another analytical text: in 'Odnos folklornog zapisa i obrade kao putokaz u analitičkom promišljanju rukoveti' 
['Relationship Between a Folk Song's Written Record and its Treatment as an Indicator for Analytical Study of a Choral Garland'] (Novi Zvuk, 14, 1999), Sonja Marinković offered a new anchorage, applicable in the analytical deliberation on choral garlands, but also on other choral works based on arrangements of folklore material. Namely, in the case study of S. S. Mokranjac's Petnaesta rukovet [Fifteenth Choral Garland], the author introduced a new analytical tool: the relationship between the original written record of a folklore material and its compositional treatment, which permits the perception of the compositional procedures from the angle of changes in text, metro-rhythmic pulsation, melody and form, but also from the perspective of the applied harmonic and textural variations of individual stanzas.

Although the work she analyzed belongs, in a wider sense, to the same genre (choral music), Branka Radović in the item 'Aleksandar Vujić: Singet dem Herrn' (Novi Zvuk, 19, 2002) pointed to another kind of cornerstone foundation in the tradition. After recalling that the analytically contoured composition by A. Vujić was written as a commission on the occasion of the $250^{\text {th }}$ anniversary of J. S. Bach, and to the same text that he used in the eponymous motet (BWV 225), it was exactly the text and the polyphonic texture that the author recognized as the natural groundwork that provoked the expected bond with the tradition of the great Baroque master, but also showed that their compositional interpretation had an equally important foundation in the time and space in which Vujić's work was composed.

\section{III}

Six authors in eight analytical texts dealt with the genre of chamber music in its diverse and varied concretizations. Ivana Vuksanović was most dedicated to it, choosing the chamber works of contemporary composers as subjects for all three of her papers published in New Sound. From the genre point of view, the 'purest' is her analytical croquis 'Milana Stojadinović Milić, Kaleidoskop - šest komada za duvački kvintet' ['Milana Stojadinović Milić, Kaleidoscope - Six Pieces for Wind Quintet'] (Novi Zvuk, 20, 2002), where the author in a well-argued manner established a clear connection between the semantic level of the title (Kaleidoscope...) of the chamber work she analyzed and its overall musical structure. The subject of the previously published item 'Divertimento Ivana Jevtića - elegancija lakog' ['Divertimento by Ivan Jevtić - Elegance of Lightness'] (Novi Zvuk, 17, 2001) was, however, a composition written for two violoncellos and string orchestra, which, although remaining in the domain of chamber sound, already steps away towards the concert genre, by its very nature. After presenting the 'identification card' of the analyzed work and noticing 
'at first sight' its multi-genre nature, the author offered to us a 'deeper insight' into the particulars of its structure and a short 'personal note', before she gave us 'instructions for listening' at the end of the paper. By talking about Ivana Vuksanović's texts in a reverse chronological order of their publication in the magazine, we thus arrive at her first item: 'Elementi popularnih žanrova u delima mladih srpskih kompozitora' ['Elements of Popular Genres in the Works by Young Serbian Composers'] (Novi Zvuk, 13, 1999). In dealing with the modes of the impact of popular genres on the creation of the younger generation of Serbian composers, she there reports the results of research focused on a diverse pool of works by Predrag Milojković (Blue - for accordion, harp and percussion), Milica Paranosić (Scarabeus - for electronics), Isidora Žebeljan (Igra [Dance] - for alto saxophone, double bass, piano and goblet drum), Goran Kapetanović (Speed - for symphony orchestra) and Ana Mihajlović (Their Silence - for alto, piano, alto saxophone and double bass).

While the genre polysemy in the abovementioned paper stems from the fact that the author recognized the same kind of particularly embodied influences of popular genres in several compositions by various authors, Marija Masnikosa's item 'Dual Vladimira Tošića' ['Dual by Vladimir Tošić'] (Novi Zvuk, 29, 2007) also deals with genre polysemy although the subject analyzed is a single piece by Vladimir Tošić. The composer, namely, rendered the same work in fourteen versions (!): from solo piano, to numerous chamber combinations of different instruments, to string and symphony orchestras. Since all the versions grew from one consistently executed idea, Marija Masnikosa relied on the string orchestra rendition for defining the procedures of the structural development of the work which are equally relevant and representative for all its manifestations.

From the angle of its subject, Sonja Marinković's paper 'Dva diptiha A. Obradovića' ['Two Diptychs by A. Obradović'] (Novi Zvuk, 18, 2001) is also non-monosemic by genre, although its form is less sizable. The dialogue between the soloist and the chamber orchestra in one of the analytically treated works (Diptih za klavir i gudače [Diptych for Piano and Strings]) places the composition into the concertante realm, while the undeniable acoustic homogeneity of the string ensemble in the second composition (Diptih za gudače [Diptych for Strings]) does not provoke any kind of detour from the chamber domain. The fact that this item was completed only after the composer's unexpected death influenced its structure and partly reoriented the expected analytical centeredness of the text towards an in memoriam.

A work for string orchestra was also in the centre of Miloš Zatkalik's analytical interest. Since Berislav Popović, composer, was publicly known as an eminent theoretician too, Miloš Zatkalik was intrigued by the chance to offer 
the analysis of B. Popović's composition Balada za gudače [Ballad for Strings] - within the paper 'Berislav Popović: Balada o izgubljenom tonalitetu' ['Berislav Popović: A Ballad about Lost Tonality'] (Novi Zvuk, 30, 2007) - to readers as an interesting confrontation between the theoretical opinions of B. Popović and their compositional application in the work in question.

Another analytical encounter with a composition written for a larger chamber ensemble (15 players) was arranged for us by Jelena Novak in the paper 'Queer protokol Omaža: Marko Nikodijević, Mračne odaje - grobnica za Kloda Vivjea' ['Queer Protocol of an Homage: Marko Nikodijević, Chambres de ténèbres/tombeau de Claude Vivier'] (Novi Zvuk, 29, 2007). Reminding us, first of all, of the particulars of C. Vivier's life and creativity, and then analytically following the procedures that M. Nikodijević used to build the construction of his homage to the Canadian colleague, the author substantiates the expressed conviction that the possible analogy in the social status and the activities of both composers might have been an additional incentive for composing the analyzed piece.

The only paper remaining whose subject belongs to the genre of chamber music brings us back to its more authentic form. In the analytical text 'Tatjana Milošević: Spiro - o vremenu u muzici' ['Tatjana Milošević: Spyro - on Time in Music'] (Novi Zvuk, 22, 2003), Ivana Stamatović deals with a work written for the classical piano trio. Its analytical perspective, however, is not particularly classical: by defining the duality of the temporal component of the piece, which she analyzes as its significant feature, the author stresses the insistence on the structural elements that affirm the composition's developmental tissue as the consequence of a categorical conflict between the static and dynamic aspects of musical time.

\section{IV}

The concerto genre has been present in the section ever since the first issue of the newly launched magazine, where Anica Sabo published the item 'Serijalne kompozicije Bele Bartoka/Drugi koncert za violinu i orkestar' ['Serial Compositions of Béla Bartók/The Second Concerto for Violin and Orchestra'] (Novi Zvuk, 1, 1993). Conforming to the stated subtitle, the author thus chose the case study of the Concerto for Violin No. 2 as a way to research Bartók's compositional procedure in the works based on serial principles, as well as the ways in which he treated a series. After examining in great detail the features of the principal twelve-tone series, modes of its appearance, as well as the fundamentals of its modification and contraction which define its pulsation along the trajectory of diverging from and converging to its principal form, the author, in 
one of the longest papers ever published in the Analyses section (14.5 pages of text +10 pages of examples), established the particulars of a fully organized and consequently applied system whereby Bartók shaped this exceptional composition. Another encounter with the same concerto was organized for us by the same author five years later, when she published the item 'Bartokovi principi tematskog objedinjavanja ciklusa' ['Bartók's Principles of Thematic Integration of a Cycle'] (Novi Zvuk, 12, 1998). The subject hence remained the same, while the angle of its analytical consideration was changed. By focusing her perspective on the thematic level of the work, which was treated only cursorily in the previous paper, A. Sabo followed through the specifications of its functioning and defined junctions that, by an integrative effect, solidify both the internal structures of the individual movements and the cumulative homogeneity of the cycle.

In between the two said papers, A. Sabo was interested in the features of two, then, new concerto works by a Serbian composer. And again a violin concerto was involved (albeit in conjunction with another work). In the item 'Aleksandar Obradović: Koncert za violinu i gudače i Muzika za klavir i gudače - formalna koncepcija muzičkog toka' ['Aleksandar Obradović: Concerto for Violin and Strings and Music for Piano and Strings - Formal Concept of the Musical Tissue], she first reports on the perceived distinctions congruent in both concerto works and equally typical of their formal concept, and then reads the functioning of these distinctions in the continuous musical tissue of each work in turn. Such a procedure leads to acknowledgment of the distinct manner that allows for the seemingly traditional three-movement cycle of an instrumental concerto in the treated works by A. Obradović, which he composed in his full artistic prime, to obtain a deeply personal and authorial expression.

By drawing from the title determinant of the composer's comment to the work's premiere at the Review of Composers in Belgrade, Marija Masnikosa published the paper 'Neizrecivo...' ['The Incommunicable...'] (Novi Zvuk, 4/5, 1994/95), where she applied an analytical procedure to Vlastimir Trajković's Concerto for Viola and Orchestra in G Minor, Op. 23. By placing the initial centre of gravity on some kind of apparent dualism between the formal framework written in the score (division in movements) and the incongruous experience of the formal structure of the musical tissue as perceived by the listener, M. Masnikosa first substantiated her conviction that Trajković's music is essentially indifferent to traditional, predetermined formal patterns, even when they are being applied to it, ostensibly. Next, by noticing another kind of dualism, based on the functional dualism of the employed thematic reoccurrences as the natural state of permanent development, i.e. fragmented repeating, M. Masnikosa based upon this dualism an analytical process through which she 
defined the particulars of Trajković's developmental tissue, and whose results she reported to us in this paper.

An exception of a similar nature and on the same level is also suggested by Ira Prodanov's item 'Nebojša Jovan Živković: Koncert za marimbu i orkestar' ['Nebojša Jovan Živković: Concerto for Marimba and Orchestra'] (Novi Zvuk, 11, 1998). The author analytically established that the composer in this work accepted the habitual procedures of the traditional concerto cycle only outwardly: by keeping the three-movement structure as the classical external framework, he does not ground its internal realization on the usual formal patterns (I - sonata form, II - ternary form, III - rondo), but conversely, on the singularities stemming from the acoustic, technical and expressive particulars of a relatively rare solo instrument (the marimba), as well as from a sort of programme concept carried out through the entire tissue of the composition. It is the decryption of these singularities and their following through the integral tissue of the concerto that constitutes the communication plane of this analytical text.

\section{V}

In the previous period, five analytical papers were published in which the research perspective was oriented towards the works of the symphonic genre. Interestingly, they include, for the first time, items by foreign musicologists. Apart from dealing with works of one and the same genre, the papers are related by the fact that their subjects, as a rule, are early symphonic works by foreign authors, rarely performed in our midst.

Offering readers a sketch for the portrait of her renowned compatriot - in the item 'Druga simfonija Osvaljdasa Balakauskasa: tekst i kontekst' ['Bmopaя симфония Освальдаса Балакаускаса: текст и контекст'] (Novi Zvuk, 8, 1996) - Lithuanian musicologist Gražina Daunoravičienè achieved this in precise strokes of her analytical handwriting, although these, as she herself noted, were unexpectedly located subject-wise. Namely, she drew the main lines of the composer's portrait along the contours of a relatively early symphonic composition (1979); from the text of the symphony, but from its context too, she read numerous peculiarities that would manifest themselves to a greater extent in his oeuvre only in subsequent years. Therefore, by perceiving in the analyzed text the traces of its contextualization, G. Daunoravičiene therein pointed not only to the determinants with which Balakauskas's opus resonates at the level typical of the creative circle which, in her conviction, he belongs to (Boulez, Ligeti, Xenakis...), but also to the properties that individualize that opus, thus making it atypical. 
Branka Radović's paper 'Prva crnogorska simfonija. Ilija Lakešić: Simfonija br. 1 u G-duru' ['The First Montenegrin Symphony. Ilija Lakešić: Symphony No. 1 in G Major'] (Novi Zvuk, 11, 1998) deals with a composition that, being a university degree work, cannot ground its importance only on the artistic level reached, but also on its own position within the space of a national culture in which it stands as the initiator of a genre. By analytically following through the continuous development of the symphony, and being aware of what was previously said, the author of the item points to the traces imprinted in the composition by the defined curricular requests it had to meet and the extremely powerful creative authority of Lakešić's mentor (J. Slavenski), but also to those of its features that, due to the melodic and rhythmic ingrainedness in Montenegrin folklore, defined the space of the national identification of the work (when B. Radović's analytical text was published, Ilija Lakešić belonged among domestic authors, but by a combination of social circumstances, as we write these lines he no longer does!)

Romanian musicologist Laura Manolache, in the item 'Stilski pregled muzike Tiberijua Olaha sa posebnim osvrtom na Simfoniju br. 2' ['A Stylistic Overview of the Music by Tiberiu Olah with Reference to Symphony No. 2'] (Novi Zvuk, 29, 2007), presented an author less known in Serbia, even in professional circles. Maybe that was the very reason why, in this musicological croquis, she first dedicated ample space to communicating the composer's biographical data and the list of his most significant works, and only then, through short analytical reviews of a few compositions, pointed to the stylistic distinctions of his opus. It was surprising, however, that the special review of the Symphony No. 2 , announced in the paper's title, was reduced to a mere twenty or so lines at the end of the text.

The initial symphonic oeuvre of Alfred Schnittke - a turning point for his overall creative activity and, in certain opinions joined by the author of the published text, controversial - drew the attention of Milena Medić, who in an extensive paper 'Dramaturške funkcije improvizovanih segmenata forme u Prvoj simfoniji A. Šnitkea' ['Dramaturgic Functions of Improvised Formal Sections in A. Schnittke's First Symphony'] (Novi Zvuk, 32, 2008) directed her analytical focus to the creative space that the composer in this work opened for the always different, improvisational contribution of its performers. She did that not only to try and understand the reasons why the composer employed this procedure, but also to answer the question of what the creative spaces, opened in this way, signify, represent or mean. Milena Medić thereby stated that the composition - subtitled even by the composer personally, in various occasions, as a nonsymphony or anti-symphony/symphony - was created within the traditional, external formal framework (four-movement symphonic cycle), through which it 
actually declared its deep ingrainedness in centuries-long stratifications of compositional experience, but at the same time, its numerous and openly manifested individual features represent a radical breakaway from precisely this centurieslong experience. With a detailed research insight into the continuously examined integral tissue of the work and by following through the particular forms of carrying out the aforementioned dichotomy, she travelled the path towards the interesting musicological results reported in this item.

The last item whose subject belongs to the symphonic genre was published recently, in the previous issue of New Sound. It is a paper by Slovenian musicologist Gregor Pompe 'Palimpsest i/ili tehnička parodija: odnos između modernizma i postmodernizma u kompoziciji Talis Petera Ružičke' ['Palimpsest and/ or Parody Technique: The Relation between Modernism and Postmodernism in Peter Ruzicka's Composition Tallis'] (Novi Zvuk, 39, 2012). Although it is conceivable that the content of this item is still fresh in the reader's memory, we will nevertheless indicate its main features. First of all, the author realizes the need, as imposed by the very subject of the analytical deliberation, to dedicate the introductory discussion to the perception of dilemmas introduced in the technical term 'Post-Modernism' by its linguistic-constructional prefix 'post' that distinguishes it from Modernism on the defining plane. And the subject of analytical deliberation is an orchestral work whose title (Tallis) clearly steers us towards the source of the composer's ideas (the opus of the English Renaissance composer Thomas Tallis), and the subtitle (Einstrahlungen für großes Orchester [Radiations for Large Orchestra]) suggested the procedures of the implementation of these ideas in a typically post-modern texture. Deeming that the composition could be interpreted as a standard example of the application of the 'music about music' concept, which he says is distinctive for P. Ruzicka, G. Pompe next analytically followed the traces of T. Tallis's music in the acoustic parchment of Ruzicka's score, but also the composer's procedures that rendered these traces - implemented either as allusions or legitimate materials - both hidden and uncovered.

\section{VI}

All that remains is to remind the reader of the seven papers whose individual singularities nuance the presented range of items grouped according to the genre affiliation of the analyzed works.

Already at the beginning of 'Muzika za balet Isidora - sa stanovišta korišćenja citata' ['Music for the Ballet Isidora - from the Aspect of Using Quotations'] (Novi Zvuk, 10, 1997), Ana Kara-Pešić noted that it was an authorial team project, and that certain creative decisions at the level of the acoustic transposition of the ballet's dramaturgical topic that follow from, but not 
only from, that fact, defined its entire musical layer which was the subject of her item. Taking the view that Ivana Stefanović's music, although directed by the libretto whose specific markers it often follows, successfully fought for its own status, autonomous with respect to the stage production, the author of the paper in which she reports on the results of her exploratory inspection pointed to the structural procedures by which the composer carried out the multi-genre spectrum of her score. Thereby, the focus of her attention is turned to those segments of the musical tissue which clearly manifest a direct reliance on other authors' materials, or discussions with them, and which promote citations as the fundamental determinative of the rich compositional gamut.

In the paper 'Žan-Klod Rise i nove muzičke tehnologije: ključna reč - kompjuter' ['Jean-Claude Risset et les nouvelles technologies musicales: l'ordinateur, maître-mot'] (Novi Zvuk, 21, 2003), the French composer and music writer Olivier Meston reminds readers that the basic singularities of J.-C. Risset's compositional opus follow from the conjugation of art and science, and that his research into numerically generated sound determined his compositional oeuvre. After that, through case studies of Risset's individual works he suggests basic procedures that the composer used to explore the infinite possibilities offered to him by a machine (computer) and stresses the central driving principles that guide the composer: perception as the focus of the research; the composing of sound instead of composing by sound. The paper ends with a comprehensive list of the works composed by then, as well as a short biography of J.-C. Risset.

The particularity of Michael Austin's item 'Studija slučaja u analizi multimedija korišćenjem alatki savremene semiologije' ['A Case Study in Analyzing Musical Multimedia Using Unités Sémiotiques Temporelles'] (Novi Zvuk, 38, 2011) lies both in the subject it deals with and in the innovative methodological tool it introduces. By applying the system of Temporal Semiotic Units (Unités Sémiotiques Temporelles, USTs), developed in Marseille Music and Informatics Laboratory (Laboratoire Musique et Informatique de Marseille), in this text he substantiates his conviction that the results he obtained by an analytical case study of a particular audio-visual multimedia structure (Three Tales, Part III, Dolly), signed by Steve Reich (music) and Beryl Corot (video), can encourage the research of deeper semantic insights, impracticable with traditional methodology, even when analyzing non-multimedia acoustic works. What is expressed in the text serves, therefore, as an example, but also as a provocation for a more detailed recognition of the analytical methodology that the author uses.

The singularity that partly diverges from analytical procedures, but is nevertheless deeply ingrained in them, was offered by Predrag Repanić in the item 
'Feniks - kanon Non nobis, Domine - ili Ka novom krugu zvuka beskonačnog kanona' ['Phoenix - Canon Non nobis, Domine - or Towards a New Cycle of Sound of the Endless Canon'] (Novi Zvuk, 33, 2009). By directing his exploratory interest to a vocal canon that has been the centre of the creative attention of many composers and musicologists, the author, by the nature of things, put himself in a position that implied methodological innovativeness. On the other hand, to gain truly innovative solutions, P. Repanić first had to walk the usual path, i.e. to analytically identify the chosen subject from the historical, stylistic and theoretical aspect, and then to play, as a researcher, with the conceivable polymorphism of its imitational potential. Since the author is also a composer who is playing, he indulges in some minor adjustments of the original thematic material and thus obtains a result that is somewhat surprising even to him: including the resolutions identified earlier and around twenty new ones, he records the grand total of 27 different ways in which the canon could be sung! After this result, which is still largely analytical and theoretical, the composer comes to the fore, having previously been present only casually, and the paper takes an unexpected turn: what emerges is a complex authorial rendition of the canon's theme, which by its fresh and contemporary sound confirms the modern vitality of the air Non nobis, Domine, and thus crowns the theoretical research in a surprising, but appropriate way.

With a subject that diverges from a concrete musical work or genre, but remains within the domain of music, Danijela Kulezić in 'Audiovizuelna struktura filma i uticaj poetike mita na njeno sazrevanje' ['The Audio-visual Structure of Film and the Influence of the Poetics of Myth on its Maturing'] (Novi Zvuk, 9, 1997) deals with particular qualities in the development of cinematic art defined at the level of feedback in the correlation between the acoustic and the visual. Reiteration of the fact that music itself was the acoustic layer that appeared even before the silent movies (originally performed during showings of silent movies to cover the noise of the cinema projector) is the starting point from which the author follows the key moments in the historical development of the function of the musical layer in a film. Therein, she pinpoints those filmmakers who played a significant role as founders (Sergei Eisenstein, Jean Cocteau) or revolutionaries (Alfred Hitchcock), but also to the important overtones lent to the maturing process by the mythologization of a film's narrative, visual and musical structures.

An unusual analytical angle taken in Ivan Čolović's paper 'Balkan u jednom narativu o world music u Srbiji' ['The Balkans in a Narrative about World Music in Serbia'] (Novi Zvuk, 24, 2004) leads to the result whose central overtones are partly dislocated from the domain of the particular musical subject. Namely, the author focuses his participation in the debate on the World Music 
category on the reading of polysemic stratifications obvious at the semantic level of syntagms of musical terminology based on the topos of the Balkans. Deriving his conclusions mostly from oral or written testimonies of a larger number of performers established in the musical genre he investigates, I. Čolović points to those semantic layers which enrich the narrative on the music of this region by a priori determinatives (being ancient, authentic, natural, unrestrained...), stemming precisely from the toponym 'Balkans'. The author reminds the reader that the terminological syntagms of this kind are double qualificatives, i.e. that they have, at the same time, differential meanings (e.g. Balkan as opposed to Oriental), and that the stereotypes based on them need not come from outside, but that they can adapt to the current social environment.

It is no accident that the last in this group is Anica Sabo's item 'Problemi koji se tiču terminoloških definicija elemenata strukturalnog nivoa muzičkog toka - muzička fraza' ['Problems Concerning the Terminological Defining of Elements of the Structural Level of the Musical Tissue - the Musical Phrase'] (Novi Zvuk, 27, 2009). Dealing with an issue from the domain of musical syntax, the author maintains her interest at the level of scientific 'ivory-towerism', i.e. of the theoretical and terminological aspects of the theory itself. Thus, the paper has distinctive characteristics compared to all the other texts published in the Analyses section, whose subjects were works of art. Its distinctions are thus not exhausted, because the author places it in the context of the items by other authors, who consider the same problem area, and carries it out as an ongoing process which will not yield final, but only forthcoming answers to numerous and diverse dilemmas perceived in practice or in the presented opinions of other authors (Berislav Popović, Tatjana Ristić, or Miloš Zatkalik/Olivera Stambolić). Unconvinced that comprehensive systematic solutions can be thoroughly applied in the current moment, the author at the end argues that at least some attitudes initiated by the stated dilemmas should be specified and coordinated, within the realm of the possible.

\section{INSTEAD OF A CONCLUSION}

As the only one whose subject steps out of the domain of the artwork, the last presented paper by Anica Sabo is in resonance with Ivana Ćojbašić's item 'Klavirska sonata Sofije Gubajduline', discussed at the beginning, which is also the only one that treated a solo piece. Therefore, these two papers frame and complete this clear insight into thirty authorial papers published during the twenty years of the Analyses section in the New Sound magazine. We believe that even those who share the belief that every analysis of a musical (artistic) work should in fact be its analytical interpretation (and those include the author 
of this text) will agree that the published text confirmed the appropriateness of the Editorial Board's original decision that, alongside Studies, Interpretations and New Works sections, the Analyses section should also be included in the magazine.

Translated by Goran Kapetanović

\section{REFERENCES}

Austin, Michael: 'A case study in analyzing musical multimedia using Unités Sémiotiques Temporelles', New Sound, 38, 2011, 87-95.

Vuksanović, Ivana, 'Elementi popularnih žanrova u delima mladih srpskih kompozitora', Novi Zvuk, 13, 1999, 85-98.

Vuksanović, Ivana, 'Divertimento Ivana Jevtića - elegancija lakog', Novi Zvuk, 17, 2001, 71-75.

Vuksanović, Ivana, 'Milana Stojadinović Milić, Kaleidoskop - šest komada za duvački kvintet', Novi Zvuk, 20, 2002, 91-95.

Daunoravičene, Gražina, 'Druga simfonija Osvaljdasa Balakauskasa: tekst i kontekst', Novi Zvuk, 8, 1996, 43-50.

Zatkalik, Miloš, 'Berislav Popović, Balada o izgubljenom tonalitetu', Novi Zvuk, 30, 2007, 129-147.

Kara-Pešić, Ana, 'Muzika za balet Isidora - sa stanovišta korišćenja citata', Novi Zvuk, 10, 1997, 111-124.

Kulezić, Danijela, ‘Audiovizuelna struktura filma i uticaj poetike mita na njeno sazrevanje', Novi Zvuk, 9, 1997, 59-64.

Manolake, Laura, 'Stilski pregled muzike Tiberijua Olaha sa posebnim osvrtom na Simfoniju br. 2', Novi Zvuk, 29, 2007, 53-59.

Marinković, Sonja, 'Odnos folklornog zapisa i obrade kao putokaz u analitičkom promišljanju rukoveti', Novi Zvuk, 14, 1999, 61-73.

Marinković, Sonja, 'Dva diptiha A. Obradovića', Novi Zvuk, 18, 2001, 89-97.

Masnikosa, Marija, 'Neizrecivo...', Novi Zvuk, 4/5, 1994/95, 73-82.

Masnikosa, Marija, 'Dual Vladimira Tošića', Novi Zvuk, 29, 2007, 60-66.

Medić, Ivana, 'The Dramaturgical Function of the Improvisatory Segments of from in Alfred Schnittke's First Symphony', New Sound, 32, 2008, 243-258.

Meston, Olivije, 'Žan Klod Rise i nove muzičke tehnologije: ključna reč - kompjuter', Novi Zvuk, 21, 2003, 87-93.

Nikolić, Miloje, 'Razvoj forme rukoveti u srpskoj horskoj muzici između dva svetska rata', Novi Zvuk, 2, 1992, 63-82.

Nikolić, Miloje, 'Rukoveti i srodne forme u srpskoj horskoj muzici posle drugog svetskog rata', Novi Zvuk, 6, 7, 1995, 1996, 111-122, 47-62.

Novak, Jelena, 'Queer protokol Omaža, Marko Nikodijević, Mračne odaje - grobnica za Kloda Vivjea', Novi Zvuk, 29, 2007, 67-76. 
Pompe, Gregor, 'Palimpsest and/or parody technique: the relation between modernism and postmodernism in Peter Ruzicka's composition Tallis', New Sound, 39, 2012, 91-108.

Prodanov, Ira, 'Nebojša Jovan Živković: Koncert za marimbu i orkestar', Novi Zvuk, 11, 1998, 83-97.

Radović, Branka, 'Prva crnogorska simfonija. Ilija Lakešić: Simfonija br. 1 u G-duru', Novi Zvuk, 11, 1998, 99-107.

Radović, Branka, 'Aleksandar Vujić: Singet dem Herrn', Novi Zvuk, 19, 2002, 75-79.

Repanić, Predrag, 'Phoenix - Canon Non Nobis, Domine: or Towards the new cycle of the sound of the endless canon', New Sound, 33, 2009, 57-79.

Sabo, Anica, 'Serijalne kompozicije Bele Bartoka/Drugi koncert za violinu i orkestar', Novi Zvuk, 1, 1993, 113-137.

Sabo, Anica, 'Aleksandar Obradović: Koncert za violinu i gudače i Muzika za klavir $i$ gudače - formalna koncepcija muzičkog toka', Novi Zvuk, 3, 1994, 85-96.

Sabo, Anica, 'Bartokovi principi tematskog objedinjavanja ciklusa', Novi Zvuk, 12, 1998, 91-103.

Sabo, Anica, 'Problematika terminološkog određenja elemenata strukturnog plana muzičkog toka - muzička rečenica', Novi Zvuk, 27, 2009, 72-82.

Stamatović, Ivana, 'Tatjana Milošević, Spiro - o vremenu u muzici', Novi Zvuk, 22, 2003, 63-67.

Ćojbašić, Ivana, 'Klavirska sonata Sofije Gubajduline', Novi Zvuk, 15, 2000, 101-115.

Čolović, Ivan, 'Balkan u naraciji o World muzici u Srbiji’, Novi Zvuk, 24, 2004, 59-62. 